\title{
The Concepts of Forest Governance Practices at Site Level in Indonesia
}

\author{
Longgak Arianto Tampubolon ${ }^{\mathrm{a}} *$ \\ ${ }^{a}$ Kementerian Lingkungan Hidup dan Kehutanan/BPHP Wilayah II Medan
}

\section{INFORMASI ARTIKEL}

\section{Article history:}

Data submission : 10 January 2018

$1^{\text {st }}$ revision: 11 February 2018

Accepted: 13 February 2018

Available online: 12 May 2018

Keywords: forest governance, hutan tanaman rakyat, hutan desa, hutan kemasyarakatan, kemitraan

\section{ABSTRACT}

This paper aims to explore the concept of forest governance practices at site level in Indonesia. It carried out content analysis by analyzing governmental regulations and related case studies from various authors. Indonesia recognizes four kinds of forest governance at site level such as hutan tanaman rakyat, hutan desa, hutan kemasyarakatan and kemitraan. All forms need local community involvement. The former three have connection with government, meanwhile the latter involves forest-related license. Some studies show their positive impact not only for community livelihoods but also for forest ecosystem. However, the common problems emerged from these implementations are characterized by weak local capability and bureaucratic process.

2018 FIA UB. All rights reserved.

\section{Introduction}

Forest governance is essential not only for many stakeholders but also for forest itself since forest management practices did not accommodate site-level needs. Previous management regime characterized by highly centralized authority and purely economic orientation has led to massive destruction of forest ecosystem and neglecting forest-border communities.

The increasing international awareness on forests and indigenous people has led radical shift in forest governance. Authority on forest is decentralized and local interests are now more accommodated in forestry activities. Furthermore, more importantly many policies give room for local societies to access forests and to receive benefits from it.

Forest governance forms in many kinds depend on countries. However, some commonalities such as collaboration, equality, transparency, and accountability are recognized. This paper aims to explore the practices of forest governance at site level. It answers questions such as what are the practices of forest governance at site level in Indonesia? and how are they implemented?.

\section{Theory}

Although the term governance is defined and demonstrated in many different ways, it displays many common characteristics. Its core features include the fragmentation of authority and policy functions among governmental and nongovernmental actors (Krahmann, 2003). For Peters and Pierre (1998), governance is a kind of prescription for steering society through less direct means and weakening the power of the State to control policy.

Governance is a broad term, embracing a varied set of factors and a multiplicity of actors. It includes complex actions and interrelations (World Bank, 2009). In Steurer's (2013) argument, governance became a catch-all concept for various forms of steering by state and non-state actors at all geographical levels and even across them. Moreover, Howlett and Ramesh (2014) said that governance is about establishing, promoting and supporting a specific type of relationship between governmental and non-governmental actors in the governing process. The objective of governance is government steering or directing key actors to perform desired tasks in pursuit of collective goals.

\footnotetext{
* Corresponding author. Tel.: +62-341-553737; e-mail: ltamputampubolon@ gmail.com
} 
Governance reforms have been at the center of policy discussions in both developed and developing countries since the 1980s (Howlett and Ramesh, 2014). Many of these reforms can be characterized as efforts to shift an existing governance mode to another mode involving a less direct role for government (Treib, Bahr, \& Falkner, 2007). Baumann (1998) argues that local protests directed at state monopoly over commercial extraction and restrictions on subsistence use of the forests become one of triggers in paradigm shift in forestry regime.

Ribot (2004) says that decentralization reforms conducted by many developing countries directly involve natural resource transfers, these reforms are important to environmental management because they are transforming the local institutional infrastructure on which local natural resource management depends. Decentralization is changing the kinds of authorities that make decisions over natural resources; the kinds of decisions that these authorities are empowered to make; and the relations of accountability between the central state, local government, other local institutions, and the local population. These reforms have implications for the way in which local people can derive benefits from natural resources, and how they value, manage, and use them.

Forest sector governance is defined as the modus operandi by which people, stakeholder groups, and institutions (both formal and informal) acquire and exercise authority in the management of forest resources, to sustain and improve the quality of life for those whose livelihood depends on the sector (World Bank 2008).

Forest governance is a generic term for describing the way in which people and organizations rule and regulate forests. This relates to how they allocate and secure access to, rights over, and benefits from forests, including the planning, monitoring, and control of their use, management, and conservation (FAO, 2012). It emerged in response to a changing vision of the roles and responsibilities of the government vis-à-vis other stakeholders: from an 'old' style of governance - where the government is steering - to a new conceptual understanding in which several actors are co-steering. In the latter vision, the government does not bear sole responsibility for governance, but every actor has a role with specific responsibilities. The term forest governance is to a large extent non-normative in that the concept does not describe or refer to any particular 'type' of governance system, but in general there is broad agreement on what forest governance relates to.

In a simple way, many scholars conclude governance as collaboration (Fairholm, 2010). This mode of governance brings multiple stakeholders together in common forums with public agencies to engage in consensus-oriented decision making (Ansell and Gash, 2007). In the recent public administration studies, collaborative management has become a prominent and much debated issue with many scholars and the importance of public participation in public policy process has been revealed from their findings (Kumar, 2007). Collaborative governance has emerged as a response to the failures of downstream implementation and to the high cost and politicization of regulation. It has developed as an alternative to the adversarialism of interest group pluralism and to the accountability failures of managerialism (especially as the authority of experts is challenged). More positively, one might argue that trends toward collaboration also arise from the growth of knowledge and institutional capacity. As knowledge becomes increasingly specialized and distributed and as institutional infrastructures become more complex and interdependent, the demand for collaboration increases (Ansell and Gash, 2007). Consequently, these developments are forcing public agencies to enter into collaborative arrangements with citizens as individuals or groups (communities) by treating them as partners in the process of governance and development.

The term of collaborative forest management is differently used by many users such as participatory forest, joint forest management, community forestry, community-based forest management, co-management, and community-based co-management. Warah (2008) defines participatory forest management as an arrangement where key stakeholders enter into mutually enforceable agreements that define their respective roles, responsibilities, benefits, and authority in the management of defined forest resources.

According to Sikor (2006), three perspectives that have informed research on the social relationships and practices constituting forestry on the ground: the local, the political, and agrarian perspective. From local approach, it proves highly productive, generating new insights into local forest relations: local people actively manage forests, have detailed knowledge of forest and soil conditions, employ a range of forest management practices, produce a variety of domestic plants in their fields, and collect many other plants of value to them. From political approach, it emphasizes the contested nature of access to and control over forests and the embeddedness of these contestations in broader power relations. It locates the political forest in the material and symbolic struggles between diverse kinds of actors, in particular between state actors and villagers and between men and women. From agrarian perspective, it situates forest relations at the intersection of local level processes and larger economic and political forces. The notion of agrarian, which is not the same as agricultural, goes beyond the idea that forests are part of broader rural dynamics.

The agrarian perspective therefore has direct implications for efforts to promote community-based forestry $(\mathrm{CBF})$. As the social relationships and practices constituting forestry on the ground depend on local people's relations with larger economic and political forces, forest policy can seek to alter those in favor of community-building processes. Advocacy for CBF may have achieved the recognition of collective actors and customary sources of authority. Yet there is still a lot of work to be done helping collective actors to improve their decision-making processes, enhancing the objects of value to them, increasing their position in property, 
governance and access relations, and strengthening customary sources of authority (Sikor, 2006).

\section{Research Method}

This paper employed content analysis and used secondary data such as regulations and existing literature. Regulation used in this paper are Governmental Regulation No. 6 of 2007, Ministry of Forestry's Regulation No. P.55/Menhut-II/2011, P.89/Menhut-II/2014, P.88/Menhut-II/2014 and P.39/Menhut-II/2013. Literature are chosen based on their relation with interest i.e. forest governance. Case studies are preferred from developing countries and have similarities with Indonesia's condition.

\section{Results and Discussion}

Community rights on involvement in managing state forests have been recognized by government. This recognition is explicitly listed in Governmental Regulation No. 6 of 2007. It says that community involvement can be done through hutan tanamn rakyat (community plantation forest), hutan desa (village forest), hutan kemasyarakatan (community forestry), and kemitraan (partnership). The three former forms are conducted in no-permit areas, meanwhile the latter is otherwise.

\subsection{Hutan Tanaman Rakyat (HTR)}

Hutan Tanaman Rakyat (HTR) can be given on unproductive production forest. It aims to increase the potency and quality of production forest by applying silviculture technique in order to sustain forest resources. The area is allocated and designated by Ministry of Environment and Forestry (MoEF) through regent/mayor's proposal. However, since the enactment of Law No. 23 of 2014, which recalls forestry autonomy from district government to provincial government (this law replaced Law No. 32 of 2004), authority in proposing the area is unclear. Subject of permit are individuals - in form of group - and cooperatives. An individual can be granted area of maximum 15 ha, meanwhile a cooperative is 700 ha. Permit holders develop HTR through three alternatives mechanisms such as self-development, partnership, and developer.

To obtain permit, applicants must apply to regent/ mayor. Prior to issuance, central forestry agency verifies the application through administrative and technical verification. Once it issued, it is valid for 65 years and can be extended for 35 years. Permit given by government is in form of izin usaha pemanfaatan hasil hutan kayu pada hutan tanaman rakyat (IUPHHK-HTR). It is called utilization because it applies intensive silviculture method and aims in commercial way. Local communities and permit holders can be facilitated by HTR field-officer appointed by regent/mayor. To develop timber plantation, permit holders can also be assisted by Pusat Pembiayaan Pembangunan Hutan $(\mathrm{P} 3 \mathrm{H})$ through loan. Its management activities are stated in long-term and annual work plan. These work plans must be submitted in order to get endorsement.

\subsection{Hutan Desa (HD)}

Hutan Desa (HD) can be given on protected and production forest and its location is under administrative area of related village. It is intended to give village access in managing forest resources sustainably through so-called Lembaga Pengelola Hutan Desa (LPHD) and aims to increase village prosperity sustainably. LPHD is a communal institution defined by village regulation and is responsible to village head. Permit given by government is in form of management right.

HD development is based on benefit and sustainability ecologically, economically, socially and culturally; deliberation; and fairness. To carry out these base, it must comply principles such as:

a) Prohibition in transferring or pledging concession;

b) Prohibition in forest area use for interests outside management plan;

c) Utilization in designated area only;

d) Considering biodiversity and cultural diversity;

e) Developing forest products and services diversification;

f) Improving village prosperity sustainably;

g) Community as a leading role;

h) Legal certainty; and

i) Public transparency and accountability.

Prior to permit issuance, the area must be designated by MoEF, and intended villages must be facilitated to establish LPHD. Area proposal can come either from village head or from governmental agencies. In the former proposal, village head proposes the intended area to regent/mayor so that regent/mayor gives recommendation to MoEF. According to this recommendation, MoEF conducts related analysis and decides to set the area. Meanwhile, authorized governmental agencies can propose the area after coordinating with other agencies. During the development process, village and LPHD can get assistances from many parties such as governmental agencies, non-governmental organizations, corporates, and individuals. These assistances are in form of:

a) Trainings and courses;

b) Establishment and development of communal institution;

c) Area proposal;

d) Direction on boundary arrangement;

e) Guidance on making work plan;

f) Business development;

g) Assistance on technology; dan

h) Access to market and capital.

After the area is designated, governor issues management right decree. This right is valid for 35 years and can be extended after being evaluated.

Right holder has an obligation to set management plans. They consist of management right work plan, village forest work plan, and village forest annual plan. The plan period are 35 years, 10 years, and 1 year, respectively. Long- and middle-term plan contain management of protected and utilization area, institutional and human resource development, and 
business plan. Middle-term plan has to be submitted to provincial forestry office to get endorsement. Further, middle-term plan is translated into more detailed and technical plan called annual work plan. This plan consists of boundary arrangement, plantation, plant maintenance, forest product extraction and harvesting, marketing, and forest protection. This plan is previously endorsed by district forestry office.

Utilization of forest area can be done in both protected forest and production forest. Both can be utilized by utilizing forest area and environmental services, and extracting non-timber forest products (NTFPs). Timber utilization is only allowed in production forest. Area utilization can be done by cultivating plants (medicinal and decorative) and mushrooms, beekeeping, wildlife breeding and swallow bird nest cultivation. Environmental services include stream flow, water, natural tourism, biodiversity and environmental protection, and carbon sequestering. NTFPs utilization includes rattan, sago, bamboo, agarwood, etc. Timber extraction is permitted only for public interest and is not tradable. Timber harvesting is allowed but in a more stringent mechanism. LPHD must form cooperative in order to submit permit and must fulfil various administrative requirements. The permit is issued by governor on behalf of MoEF. By holding this permit, the cooperative is allowed to harvest timber and sell it in accordance with timber administration.

\subsection{Hutan Kemasyarakatan (HKm)}

Although Governmental Regulation No. 6 of 2007 allows community empowerment through hutan kemasyarakatan $(\mathrm{HKm})$ on all forest functions (production, protected and conservation), Ministerial Regulation (P.88/Menhut-II/2014) excludes conservation forest. HKm is intended to develop societal capacity and to give community access in managing forest area sustainably in order to create employment, to alleviate poverty, and to solve social matters. It aims to improve local community welfare by means of forest resource utilization optimally, fairly and sustainably while maintaining the sustainability of forest and environmental functions. Its location is considered as area from which local community depend on.

$\mathrm{HKm}$ development is based on benefit and sustainability ecologically, economically, socially and culturally; deliberation; and fairness. To carry out these base, it must comply principles such as:

a) Do not change status and functions of forest;

b) Timber utilization can only be done from plantation;

c) Considering biodiversity and cultural diversity;

d) Developing forest products and services diversification;

e) Improving community welfare sustainably;

f) Community as a leading role;

g) Legal certainty;

h) Public transparency and accountability; and

i) Participatory decision making.

Central government through its regional offices coordinates with other agencies and local government to determine designate area of $\mathrm{HKm}$ and to facilitate local community making proposal based on predefined area. However, community can also propose area outside of predefined area. Local communities propose $\mathrm{HKm}$ permit to regent/ mayor and based on these applications, regent/ mayor submits the designation of area to MoEF. Further, related Director General verifies this proposal and assesses whether it can be accepted (wholly or partially) or rejected. MoEF then define the area of HKm.

During the development process, local communities and permit holders can get facilitation from many parties such as governmental agencies, universities, nongovernmental organizations, financial institutions, cooperatives, and corporates. Facilitation aims to:

a) Improve organizational capacity of local communities;

b) Assist local communities in proposing permit;

c) Improve local community capability on making work plan;

d) Improve local communities in applying silviculture by developing appropriate technology and increasing value added of forest products;

e) Improve local human resource through development of knowledge, ability, and skills;

f) Give local communities information regarding market and capital; and

g) Improve local community ability in developing forest and forest product business.

After area designation, $\mathrm{HKm}$ right is issued by regent/ mayor. This right is not an ownership right on forest land. The holders are also prohibited to transfer and to pledge right, to use it outside plan, and to change the status and function of forest. The right is valid for 35 years and can be extended after being evaluated.

\subsection{Kemitraan}

Kemitraan kehutanan (forestry partnership) is a collaboration between local communities and forestrelated license holders in developing capacity and granting access, on the basis of equality and mutual benefit. Some principles must be adopted such as:
a) Agreement;
b) Equality;
c) Mutualism;
d) Specific location;
e) Trust;
f) Transparency; and
g) Participation.

Partnership become an obligation for any forestrelated license holder. It runs based on agreement between both parties. This agreement must be signed by both parties and must be known by head of village or head of sub-district. To strengthen local capacities, communities can get some assistances from government. However, to guarantee its process, government needs to verify them and to decide which candidates entitled to facilitate. Kinds of facilitation include socialization, 
group establishment, and institutional development. Appointed area is maximum 2 ha for each household.

\subsection{Lessons From Experiences}

This paper is limited on conceptualitation. To get a clearer image, some literature on forest governance are revealed. These include studies from India, Nepal, Cameroon, Brazil, and Indonesia.

\subsubsection{India}

Corbridge and Jewitt (1997) conducted a study on joint forest management (JFM) in Ambatoli village in Bero Block, Ranchi District, Bihar State in 1993-1994. Their study reveals that to join JFM, community must establish Village Forest Protection and Management Committee (VFPMC), and this establishment need formalisation by the Forest Department. The format and workings of VFPMCs are shaped largely by the requirements of JFM as it is practised in the State of Bihar.

The gist of the policy is as follows. First, the government is the forest owner and local users are responsible under JFM for the daily management. Furthermore, household participating in a VFPMC is required to acknowledge the State's monopoly rights by paying a nominal royalty (set in $1994 / 95$ at $20 \%$ of the surplus timber generated under JFM). Second, and remarkably given past practices, it is the intention of JFM in Bihar that responsibility for new planting decisions is devolved to the VFPMCs. Third, rights and responsibilities are brought together meaning that participating households in a VFPMC are required to draw up a rota for forest protection and surveillance activities. Fourth, the $80 \%$ of the surplus timber grown under JFM schemes should be returned to the VFPMC. The resulting income will be returned to the VFPMC in three tranches: a first tranche for further afforestation work, a second tranche for village improvement schemes such as road-building and irrigation, and a third tranche for participating households as stakeholders.

Daily management of the tree stock is considered to be democratic and empowered local forest governance. Local forest users can opt for the planting of fruit trees such as mango, tamarind, ber, and bel as well as, or instead of, fast-growing commercial crops such as eucalyptus.

In Ambatoli, most households depend upon the jungle for construction timber, fuelwood, fruits, seeds, leaves, etc. Theoretically, all of Ambatoli's villagers are 'right-holders' in Ambatoli forest and may freely collect dry branches (for fuelwood) and minor forest produce. They may also cut large timber for house construction and plough-making purposes, so long as their requirements are determined to be bona fide by the Forest Department. In practice, forest officials have failed to recognise these rights on so many occasions that most villagers have learned to take their chances with the forest guard and help themselves to young green trees for fuelwood and large timber for housebuilding: a situation that has, in combination with local population increases, put substantial pressure on local forest resources.

This study, and few others, suggests JFM is flawed in five key respects. First, discrimination is still existed. Women and lower caste people are usually the target of this discrimination. Second, there is an incorrect view on local tribes. Instead of economic interest, for most parts, members of the VFPMC are willing to contribute time and resources to forest protection activities, and participating members are willing and able to see their local forests as a single entity for which all bear a common responsibility. Third, local citizen doubts commitment of local forest officers. Fourth, sense of belonging is still lacking. Trust and mutuality are primordial features of tribal communities, and that vocabularies of collective action and deferred gratification are somehow already in place in communities. It needs only to be ignited by new institutional arrangements. Fifth, forestry and environmental concerns must largely depend in local own terms.

\subsubsection{Nepal}

According to Nepalese policy, the use rights of the majority of accessible forests have already been handed over to local communities in form of community forest user groups (CFUGs). Based on Nepalese Forest Act in 1993 and Forest Regulations in 1995, CFUGs are selfgoverned autonomous entities.

In Poudel, et. al.'s (2014) study on community forestry program in the Dang district towards 200 randomly-selected registered CFUGs of 447 CFUGs, the community forestry program had desirable impacts on the rehabilitation of timber forests. We found that forests handed over earlier had better stand condition. Such evidence clearly indicates that new trees tend to be regenerated after the community forest users start to manage the handed-over forests. Furthermore, population pressure not only fostered the deforestation in the past when the forests were de facto open access but also contributed to better management and the generation of more revenue per unit area in recent years due to the handover of the forest use rights.

This study also demonstrated that the community forestry program contributed to the rehabilitation, intensive management, and income generation in timber forests with high population pressure and favorable market access. In other words, community forest management seems conducive to the sustainable management of timber forests with income generation. Furthermore, to the extent that sustainable timber production is profitable, the promotion of such forests will contribute to reforestation and, hence, carbon sequestration in developing countries. Therefore, a clear policy implication of this study is to encourage the development of community-based forest management systems for timber forests.

\subsubsection{Cameroon}

Cameroonian Forestry Law No. 94/01 of 1994 and its Decree of Application No. 94/436 of 1995 are 
considered to become a milestone in forest governance, because it promotes popular participation in forest management, promotes sustainable management and contributes to the fight against poverty. Law defines a community forest as a forest $\leq 5000$ hectares in size in the non-permanent domain that is subject to a management agreement between a village community and the administration in charge of forests. It is equipped with a simple plan for its management, conservation and exploitation for the interests of the communities with the technical support of the forestry administration. All products, wood, non-wood, wildlife, fishery resources and special products, with the exception of those forbidden by law, are deemed the property of the community concerned. Most community forests in Cameroon have primarily focused on harvesting timber. The normal duration of the community forest management plan is 25 years, however, the administration retains the authority to suspend or nullify a management agreement without any prior warning to the community.

Brown, et. al. (2010) study on nine villages in the humid forest zone of Cameroon, the villages were part of three community forests, reveals that local communities have been empowered as a result of the legislation, which opened up a recognized space for forest management that was closer to local people. While significant for all forest dwellers, the change in legislation has created a sphere of social recognition particularly for marginalized groups. The legislation has also helped to curtail the exodus of rural youth to cities. The prospect of accessing their ownshare of the abundant forestry resources has encouraged them to stay in the village. While many young people had felt marginalized from access to forest benefits, the principle of community forest management has fostered the potential for social negotiation between older and younger generations, as well as the potential participation of women.

However, there are few constraints that must be faced. First, the complicated process for obtaining a community forest. Second, the law does not adequately define a 'community' within the cultural reality of Cameroon. Third, the law specifies that the management agreement must be between the state forestry administration and a legalized group from the community, which can take any of four forms: associations, common initiative groups, economic interest groups or cooperatives. This completely ignores traditional systems of natural resource management and accountability in Cameroon. Fourth, conflict among stakeholders is still existed, especially on powers and legitimacies over forests and other common property resources. From an ecological perspective, community forests do not seem to be sustainably managed. Although artisanal logging is the recommended method for community forests, communities often opt to contract to an external industrial operator for the more immediately profitable large-scale logging. In addition, simple management plans are often not respected in the absence of control activities by the state forestry administration. The most common problems are failure to respect the logging rotation cycle and logging beyond community forest borders.

\subsubsection{Brazil}

Sattler et. al.'s (2015) conducted study on local community involvement in conservation area. They focus on Marujá community which is located the Ilha do Cardoso State Park (Parque Estadual da Ilha do Cardoso, PEIC) in São Paulo state in south-eastern Brazil. Marujá is home to about 60 families with approximately 180 inhabitants.

According to them, in response to the increasing environmental degradation, the community organized itself and founded a community association entitled AMOMAR (Associaçãodos Moradoresdo Marujá) to make their concerns heard by the park authorities. The community made a co-management agreement with park authorities, and together both parties worked out an Environmental Management Plan (Planode Gestão Ambietal, MP).

The governance change in Marujá was based on collective action among community members, which was enabled by the adherence of different principles. Primarily, the community members had a clear definition of who belonged to the community and who did not. The reference to "outsiders" is made to distinguish between the rightful traditional Residents and other people who enter into the park temporarily. Several rules are related to the overall perceived carrying capacity of the community's natural environment. The dominant is rule about limitation on natural resource utilization.

Marujá community members can participate though AMOMAR in rule making and modification. This can only be done with the participation of the community. The procedures for mutual decision making within AMOMAR are straightforward. Each traditional resident is considered a member and decisions are done by majority vote where everyone above the age of 16 is allowed to vote. Meetings are usually once a month with varying participation in dependence on discussed topics.

Monitoring activities are done as a shared task between them and others, such as environmental monitors, park guards, and also the environmental police, but with clear responsibilities. Any emerging conflict is solved by intense communication among parties.

The community's right is recognized through the MP which is a legally binding document for both parties: the community and the state park. For the state park, the recognition of the community's right to self-organize offers one important benefit: they gain a strong partner for their conservation mission. Without the support of the communities in the park, achieving conservation aims is considered unattainable.

\subsubsection{Indonesia}

Studies from Indonesia consist of local community participation in conservation forest (Kubo, 2008), 
cooperation between forest-boundary societies with state forestry enterprise in production forest (Djamhuri, 2012), social and financial feasibility of community plantation forest (Subarudi, 2014), financial feasibility of community forestry (Mulyadin et. al., 2016) and forest management practices mixed with agricultural crops (Diniyati et. al., 2013; Indrajaya and Sudomo, 2013).

Kubo (2008) conducted research on co-management in Gunung Halimun-Salak National Park. His examination explains that the Park still allows the continuous use of farmlands located within the national park area. To improve local society capacity, its officers advised the villagers to form groups for effective communication and sharing experiences. Although neither tangible nor financial benefits were offered, the six group leaders joined the meetings on a voluntary basis. This is because participating villagers see the work is important for tenure security of their farmlands within the park area; therefore, the motivation of the leaders was relatively high their communication with the leaders became more frequent. This has led to some sense of mutual trust between the leaders and the field officers.

To make it formal, the pilot project and forest conservation were introduced to local communities. They accepted the programs for two major reasons. First, the villagers felt the conditions offered by the field officer were "reasonable". The recognition by the government of continuous cultivation at existing farmlands within the national park area was fair enough for the villagers to accept and to commit to the forest conservation as trade-off. Second, the leaders played a monitoring role against illegal acts in forests. Villagers see this co-management process as a view to work together. It's mutual understanding that the national park staff wants us to protect forests and we want them to secure our farmland.

Relation between local communities and state forest company (SFC) namely Perum Perhutani was examined by Djamhuri (2012) in Blora District. Specifically, she analyzed this cooperation in form of PHBM (Pengelolaan Hutan Bersama Masyarakat/Joint Forest Management). This system aims to involve the local communities at large in the forest management, and to share the benefits derived from the management. The state that used to be the sole property rights holder of the timber has partially transferred its rights to the local communities through timber sharing.

To participate in PHBM, each forest village should form a Forest Village Community Organization (Lembaga Masyarakat Desa Hutan, LMDH). It is a village level organization representing the forest village (in this study, forest village refers to state forest land managed by SFC, WPH), and which manages the WPH together with the SFC. Each WPH was mainly defined using the forests-surrounding-village concept.

The LMDH trustee board participates in the PHBM by playing several important roles. Firstly, they organize village-level collective action for forest protection.
Secondly, they represent the forest village community's interest particularly in accessing timber sharing. Thirdly, the LMDH trustee board plays a role as cushion that eases the conflict between the SFC and the community that often occurs when the community members are punished for violating the SFC's rules.

However, the LMDH trustee board poses several negative implications. Firstly, they participate only when immediate material incentive is available for them. Secondly, the richer the WPH, the more the LMDH trustee board will receive from timber sharing revenue, thus the more they are able to finance their forest patrols. Thirdly, there is disproportionate timber sharing distribution among stakeholders within the community. Forest resources are an accumulation of long-term investments and tumpang sari (TS) farmers largely contribute to these long-term investments.

In his research, Subarudi (2014) analyzed social and financial feasibility of community plantation forest in Dompu, West Nusa Tenggara. Community plantation forest is conducted through farmer groups or cooperatives. Its main plants are sengon (Paraserianthes falcataria), gmelina (Gmelina arborea) and jati (Tectona grandis). In developing community plantation forests, they get soft loan from Pusat Pembiayaan Pembangunan Hutan Tanaman (P3HT).

He concluded that this activity is financially feasible with net present value (NPV) of IDR20,054,791, benefit cost ratio (BCR) of 3.31, internal rate of return (IRR) of $28.1 \%$. However, cooperatives burdened with additional cost such as credit agreement cost. Some challenges can also inhibit cooperatives such as lack of good-quality seeds and unidentified prospective market. Poor seeds can burden cooperatives through more efforts on management and low productivity. Even though it is profitable, many research show that the higher margin is on timber industry. Socially, this program aims to legalize community occupation on state forest, to provide employment and to increase community income. This program is also designed to strengthen local community institution.

Mulyadin et. al. (2016) has examined the BCR of community forestry between two farmer groups in Gunung Kidul, Yogyakarta. The establishment of community forestry is based on massive forest degradation and aims to develop local livelihoods. Averagely, each household manages area between 0.25 ha and 0.50 ha depends on group agreement. Its main product is jati (Tectona grandis) and it is combined with multi-purpose tree species (MPTS) and crop plantation. Their findings reveal that both groups perform feasible result with BCR is ranging from 1.87 to 19.11. All plants give certain contribution to farmers' income. Households' income from this scheme is ranging between $20 \%$ and $50 \%$ of total income. By comparing with regional minimum wage, this income is higher. However, jati production has fallen annually. Farmers tend to harvest and to sell juvenile plants. This attitude is based on farmers' needs and high demand of jati. 
Diniyati et. al. (2013) conducted study on community forest management with agroforestry in Ciamis, West Java. They found that such management of more than 0.15 ha is financially feasible. Their analysis shows that its BCR are ranging between 1.09 and 1.98. This value means that every IDR 1 of expense will result in IDR1.09 of income. Meanwhile its IRR are ranging from $10.95 \%$ to $28.80 \%$. This rate is higher than the valid commercial rate of $9.5 \%$. It means that farmers can still pay the debts from commercial banks. Similar study was conducted by Indrajaya and Sudomo (2013). They found that agroforestry system results in NPV of IDR73,952,820, BCR of 1.45 , IRR of $33 \%$. In mixing sengon and kapulaga, kapulaga gives higher proportion of income $(60 \%)$. Their finding also reveals that sengon production is more sensitive than kapulaga.

Societies use some variations in managing their lands (Diniyati et. al., 2013). The usage of lands is dominated by timber plantation, and is mixed with coconut, horticultural plants, understorey crops, and crop plants. Villagers have easy access to their lands and it can be done by walking with distance between $200 \mathrm{~m}$ and 3 $\mathrm{km}$. Agroforestry patterns are developed based on government program in 1962 and are focused on sengon (Falcataria mollucana). However, the main pant has been attacked by fungus called karat tumor. This plant disease has been spread to 12 sub-districts and has resulted in decrease in economic value of timber.

Other challenges faced by farmers are the small-scale land ownership and the fragmentation of lands. Limited area ranging from 0.01 ha to 0.15 ha is not economically feasible to develop. It can hold only limited variation in species and production. With this agroforestry pattern, farmers face negative benefit. The fragmented area also gives negative effect to farmers because it can limit plant management and consume more time in farmer movement among their lands.

\section{Conclusion}

Avoiding local existence is proved lead to more destructive forest degradation. In contrast, many scholars suggest that recognition on local communities is a need to fix this situation and to achieve sustainable forest management. As a result, local people involvement is considered to be an integral part in forest management.

Indonesia, which is one of countries with the highest deforestation rate, has realized that communities need to be given access to manage forests. Public participation is recognized through governmental regulations and is realized by the means of hutan tanaman rakyat, hutan desa, hutan kemasyarakatan, and kemitraan. Some studies show their positive impact not only for community livelihoods but also for forest ecosystem. However, the common problems emerged from these implementations are characterized by weak local capability and bureaucratic process.

\section{References}

Ansell, C. and Gash, A. (2007). Collaborative Governance in Theory and Practice. Journal of Public Administration Research and Theory, 18, 543-571.

Baumann, P. (1998). The Persistence of Populism in Indian Forest Policy. The Journal of Peasant Studies, 25, 96-123.

Brown, H. C. P. and Lassoie, J. P. (2010). Institutional choice and local legitimacy in community-based forest management: lessons from Cameroon. Environmental Conservation, 37, 261-269.

Diniyati, D., Achmad, B. and Santoso, H. B. (2013). Analisis Finansial Agroforestry Sengon di Kabupaten Ciamis (Studi Kasus di Desa Ciomas Kecamatan Panjalu). Jurnal Penelitian Agroforestry, 1, 13-30.

Djamhuri, T. L. (2012). The effect of incentive structure to community participation in a social forestry program on state forest land in Blora District, Indonesia. Forest Policy and Economic, 25, 1018.

Corbridge, S. and Jewitt, S. (1997). From forest struggles to forest citizens? Joint Forest Management in the unquiet woods of India's Jharkhand. Environment and Planning, 29, 21452164.

Fairholm, M. R. (2010). Why a Rational Move toward "Governance" may Destroy the Soul of Public Administration: Or Why Governance isn't Concerned with Government Anymore. In T. Brandsen and M. Holzer. The Future of Governance. Selected Papers from the Fifth Transatlantic Dialogue on Public Administration. National Center for Public Performance (NCPP)

FAO. (2012). Strengthening Effective Forest Governance Monitoring Practice. Rome: Food and Agriculture Organization of the United

Howlett, M and Ramesh, M. (2014). The Two Orders of Governance Failure: Design Mismatches and Policy Capacity Issues in Modern Governance. Policy and Society, 33, 317-327.

Indrajaya, Y., and Sudomo, A. (2013). Analisis Finansial Agroforestry Sengon dan Kapulaga di Desa Payungagung, Kecamatan Panumbangan, Ciamis. Jurnal Penelitian Agroforestry, 1, 123132.

Krahmann, E. (2003). National, Regional, and Global Governance: One Phenomenon or Many? Global Governance, 9, 323-346.

Kubo, H. (2008). Diffusion of Policy Discourse into Rural Spheres Through Co-Management of State Forestlands: Two Cases from West Java, Indonesia. Environmental Management, 42, 8092.

Kumar, S., Kant, S. and Amburgey, T. L. (2007). Public Agencies and Collaborative Management Approaches: Examining Resistance Among Administrative Professionals. Administration and Society, 39, 569-611.

Mulyadin, R. M., Surati, and Ariawan, K. (2016). Kajian Hutan Kemasyarakatan Sebagai Sumber Pendapatan: Kasus di Kabupaten Gunungkidul, 
Yogyakarta. Jurnal Penelitian Sosial dan Ekonomi Kehutanan, 13, 13-23.

Peters, B. G. and Pierre, J. (1998). Governance without Government?: Rethinking Public Administration. Journal of Public Administration Research and Theory, 8, 223-243.

Poudel, N. R., Fuwa, N., and Otsuka, K. (2014). The impacts of a community forestry program on forest conditions, management intensity and revenue generation in the Dang district of Nepal. Environment and Development Economics, 20, 259-298.

Ribot, J. C. (2004). Waiting for Democracy: The Politics of Choice in Natural Resource Decentralization. Washington D. C.: World Resources Institute.

Sattler, C., et al. (2015). Understanding governance structures in community management of ecosystems and natural resources: The Marujá case study in Brazil. Ecosystem Services. Available at https://www.infona.pl/resource/bwmeta1.element. elsevier-7c03eb34-3933-3b77-be46b853a6be9fa7 [Accessed on 20 March 2017].

Sikor, T. (2006). Analyzing Community-based Forestry: Local, Political and Agrarian Perspectives. Forest Policy and Economic, 8, 339-349.

Steurer, R. (2013). Disentangling Governance: A Synoptic View of Regulation by Government, Business and Civil Society. Policy Science, 46, 387-410.

Subarudi. (2014). Analisis Kelayakan Sosial, Finansial dan Pasar Produk Hutan Tanaman Rakyat: Studi Kasus di Kabupaten Dompu, Nusa Tenggara Barat. Jurnal Penelitian Sosial dan Ekonomi Kehutanan, 11, 323 - 327.

Treib, O., Bahr, H., and Falkner, G. (2007). Modes of Governance: Towards a Conceptual Clarification. Journal of European Public Policy, 14, 1-20.

Warah, S. (2008). Participatory Management of Forests and Protected Areas: A Trainers' Manual. Bangkok: Regional Community Forestry Training Center for Asia and the Pacific (RECOFTC).

World Bank. (2008). Forests sourcebook: Practical guidance for sustaining forests in development cooperation. Washington DC: World Bank.

World Bank. (2009). Roots for Good Forest Outcomes: An analytical Framework for Governance Reforms. Washington DC: World Bank. 